\title{
LASTE ESIMESED EESTIKEELSED OMADUSSÕNAD
}

\section{Tiiu Salasoo}

Estonian Learning Materials

Kokkuvõte. Kolme poolteise- kuni nelja-aastase eesti keelt loomulikult, kuid erinevates tingimustes omandava poisi lindistuste analüüs näitab, et poisid omandasid eestikeelseid omadussõnu aeglasemalt kui nimi- ja pöördsõnu ja seetõttu esines neid ka poiste lindistusleksikonis vähem. Omadussõnade kasutuselevõtu kiirus näis olevat relatiivselt sõltumatu lapse keelelisest makrokeskkonnast, nii kaua kui lapse hooldajaks on ka keegi temaga küllaldaselt eesti keelt kõnelev isik. Rohkem mõju näis aga olevat lapse individuaalsetel lingvistilistel võimetel. Vaatlusalused poisid alustasid oma nimisõnade spetsiifiliseks muutmist, nimetades neid ilusaks, heaks ja halvaks, väikeseks ja suureks, vanaks ja uueks. Nende kõnesse ilmusid varakult kontrastsed omadussõnade paarid ning hinnangulised omadussõnad. Omadussõnade ühtsus e samade sõnade kasutamine erinevate subjektide poolt oli küllaltki kõrge nii poiste endi vahel kui ka eesti poiste ja inglise laste vahel, samuti kui eesti poiste ja täiskasvanute tavakõne vahel. See viib järeldusteni, et erinevates tingimustes eesti keelt omandavate poiste omadussõnad olid representatiivsed tänapäeva eesti keele suhtes. Samuti võib oletada, et eesti poiste kasutatud varajaste omadussõnade mõisted ühtivad ka teisi keeli õppivate laste omadega.

Märksõnad: eesti keele omandamine, omadussõnad, keelekeskkond, ühtsus

Abstract. The first Estonian adjectives of children. Analysis of the recordings of three boys from the ages of 18 months until 4 years acquiring Estonian naturally in differing language environments indicated that Estonian adjectives increased relatively slowly and thus were less numerous in their recording lexicons than verbs and nouns. Adjectival rate of increase appeared to be relatively independent of a child's macro-environment (as long as there is an Estonian-speaking carer to provide sufficient input), yet it seemed to be influenced by a 
child's individual linguistic abilty. The boys started qualifying their nouns with adjectives by calling things beautiful, good and bad, small and big, old and new. Antonymous pairs of adjectives and evaluative adjectives appeared early in their speech. Adjectival commonality defined in terms of the number of the same words used by several individuals - between individual boys, the Estonian boys and children learning English, as well as the Estonian boys and adults, indicated that the observed boys' adjectives were representative of currently spoken Estonian, as well as possibly common in the early speech of all children.

Keywords: Estonian acquisition, adjectives, linguistic environment, commonality

\section{Tagapõhi ja uurimismaterjal}

Artiklis vaadeldakse, kuidas ilmuvad omadussõnad eesti keelt loomulikult omandava lapse sõnavarasse. Empiirilise vaatlusena on lindistatud kolme erinevas keelekeskkonnas eesti keelt omandava poisi spontaanseid dialooge oma vanematega. Karl-Oskar kasvas ükskeelses kodus Eestis, kaks poissi elasid ingliskeelses Austraalias. Lembitu kodus kõneldi peamiselt eesti keelt, kuigi ta austraallannast ema oli ise alles mõne aasta eest eesti keelt õppinud. Aksel kasvas sihilikult kakskeelsena hoitud kodus, kus ema kasutas eesti ja isa inglise keelt. Poiste vaatlusandmeid näeb tabelis 1 . Üksikud vaatlused on lindistaja puudumisel jäädvustatud vaid kirjalikult.

Tabel 1. Erinevas keelekeskkonnas eesti keelt omandava kolme poisi vaatlusandmed

\begin{tabular}{|c|c|c|c|}
\hline & Karl-Oskar & Lembit & Aksel \\
\hline $\begin{array}{l}\text { Keele- } \\
\text { keskkond }\end{array}$ & $\begin{array}{l}\text { eesti keel } \\
\text { Eestis }\end{array}$ & $\begin{array}{l}\text { peamiselt } \\
\text { eesti keel } \\
\text { Austraalias }\end{array}$ & $\begin{array}{l}\text { eesti ja } \\
\text { inglise keel } \\
\text { Austraalias }\end{array}$ \\
\hline Vanus & $1 ; 6 ; 0-2 ; 11 ; 26^{\#}$ & $1 ; 7 ; 6-2 ; 11 ; 29$ & $2 ; 9 ; 5-4 ; 0 ; 12$ \\
\hline $\begin{array}{l}\text { Vaatluste } \\
\text { arv }\end{array}$ & $\begin{array}{l}11 \text { lindistust } \\
+4 \text { kirjalikku }\end{array}$ & 24 lindistust & $\begin{array}{l}15 \text { lindistust } \\
+8 \text { kirjalikku }\end{array}$ \\
\hline $\begin{array}{l}\text { Lindistuste } \\
\text { kestus }\end{array}$ & $325 \mathrm{~min}$ & $226 \mathrm{~min}$ & $263 \mathrm{~min}$ \\
\hline
\end{tabular}


Karl-Oskari lindistamine algas vanuses 1;11;2.

Olen mõnda aega võrrelnud nende erinevates keeletingimustes elavate poiste eesti keele loomulikku omandamist, oletades, et ühised jooned neis kas kehtivad kõikide keelte omandamisel (vastavalt Noam Chomsky universaalsele grammatikale, 1959, 1976), või on siis tingitud spetsiifilistest eesti keele omadustest. Erinevusi poiste tulemustes võiks aga pidada kas laste erinevate keelekeskkondade ja/või nende erinevate individuaalsete omaduste ja võimete mõjuks.

Lisaks poiste eesti keele morfoloogilise ja süntaktilise arenemise võrdlemisele (Salasoo 1995, 1996, 1998a, 1998b, 1999, 2001, 2002a, 2003b) olen viimasel ajal uurinud ka laste lindistustes kasutatud sõnavara, et näha, kas selle omandamiskiirus ja koostis on mõjutatud erinevatest õppetingimustest. Eestikeelsete tegu- ja nimisõnade kasutusele võtmist olen vaadelnud kolmes artiklis (Salasoo 2002b, 2003a, 2005), siinses keskendun omadussõnadele.

Võrdlen poisse nii omavahel kui inglise keelt omandavate lastega ning ka Eestis elavate täiskasvanutega, et näha välismaal kasvavate poiste sõnavara vastavust täiskasvanute tavakeelele. Käesoleva vaatluse sihiks ei olnud lapsekeele võrdlus sisendkeelega, mille mõju on mitmed autorid tunnustanud (Naigles, Hoff-Ginsberg 1998, Ninio 1999, Flynn jt 2004, Blackwell 2005). Samuti võrdlen omadussõnade kasutusele võtmist ning esinemist nimi- ja tegusõnadega. Uurimismaterjali arvandmed on esitatud tabelis 2. Kuna nii Karl-Oskaril kui Akslil esines emapoolseid vaatlusi, mida ei olnud võimalik lindistada, siis on tabelis 2 lindistatud sõnade arv eraldatud kasutatud sõnade arvust ja kõikides edaspidistes lindistusajale baseeruvates arvutustes on kasutatud lindistatud sõnade arve.

Tabel 2. Vaatlustes kasutatud ja lindistatud eestikeelsete sõnade arv

\begin{tabular}{c|l|l|l|l} 
Sonnaliik & $\begin{array}{l}\text { Karl- } \\
\text { Oskar }\end{array}$ & Lembit & Aksel & $\begin{array}{l}\text { Erinevaid } \\
\text { kokku }\end{array}$ \\
\hline $\begin{array}{c}\text { Nimisõnad } \\
\text { kasutatud } \\
\text { lindistatud }\end{array}$ & 352 & 263 & 255 & 652 \\
\hline Tegusõnad & & 263 & 248 & \\
\hline
\end{tabular}




\begin{tabular}{c|l|l|l|l} 
kasutatud & 83 & 69 & 90 & 139 \\
lindistatud & 77 & 69 & 83 & \\
\hline $\begin{array}{c}\text { Omadussõnad } \\
\text { kasutatud }\end{array}$ & 36 & 36 & 31 & 64 \\
lindistatud & 34 & 36 & 31 &
\end{tabular}

\section{Omadussõnade juurdekasvu kiirus}

Kuna omadussõnad ei esine iseseisvalt nagu n-ö primaarsed sõnaliigid nimi- ja tegusõnad, vaid semantilises mõttes täpsustavad nimisõnu, toimides süntaktiliselt kas öeldistäitena (poiss on tark) või ühilduva täiendina (tark poiss) (EKK 1997: 140), väljendades nii nimisõnade omadusi või kvaliteeti, võiks arvata, et omadussõnu kasutatakse keeles vähem kui nimisõnu. "Eesti kirjakeele sagedussõnastikus" (Kaalep, Muischnek 2002) on 1000-st kõige sagedamast sõnast vaid 9,6\% omadussõnad. Suulises keeles on omadussõnu veelgi vähem: eesti kõnekeele korpuse argivestlustes (TÜ suulise kõne uurimisrühm 2007) oli omadussõnu vaid 3,2\% (14 091 sõnast 457). Tabel 2 näitab, et sama tendents avaldub ka vaadeldud kolme poisi eesti keele omandamisel: vaatlusperioodide jooksul kasutasid nad kokku 652 eestikeelset nimisõna ja 139 tegusõna, kuid samal ajal ainult 64 omadussõna. Nii üksikult vaadelduna kui ka kollektiivselt kasutasid poisid nimisõnu 3-4 korda nii palju kui tegusõnu ja 7-10 korda nii palju kui omadussõnu.

Et poiste tulemusi omavahel võrrelda, oli vajalik viia need samale alusele, milleks jagati iga poisi lindistatud erinevate sõnade arv (vt tabel 2) nende lindistuskestusega (vt tabel 1). Arvutuse tulemusel on saadud iga poisi sõnade juurdekasvu keskmine kiirus sõnaliikide kaupa (vt tabel 3). Eelnimetatud kalduvustega on kooskõlas ka eestikeelsete eri sõnaliiki sõnade juurdekasvu kiirus: kõige kiiremini omandatakse nimisõnu $(0,94-1,16$ sõna minuti kohta), seejärel tegusõnu $(0,24-0,31)$ ja kõige aeglasemalt omadussõnu $(0,10$ $0,16)$. 
Tabel 3. Eestikeelsete sõnade keskmine juurdekasvu kiirus lindistusminutis

\begin{tabular}{l|l|l|l} 
Sõnaliik & Karl-Oskar & Lembit & Aksel \\
\hline Nimisõnad & 1,00 & 1,16 & 0,94 \\
\hline Tegusõnad & 0,24 & 0,31 & 0,31 \\
\hline Omadussõnad & 0,10 & 0,16 & 0,12
\end{tabular}

Võiks oodata, et tänu rikkalikumale keelekeskkonnale suureneb Eestis kasvava Karl-Oskari sõnavara kõige kiiremini. Kuid kõige kiirem oli hoopis Lembitu, Austraalias sirguva poisi sõnade juurdekasv (kuigi erinevus teistest polnud statistiliselt oluline). Põhjuseks võib arvata individuaalset võimekust, millele viitas ka samade laste morfoloogiline arenemine, kus Lembit eksis väga harva tegusõnade (Salasoo 1998a) ja nimisõnade vormide (Salasoo 2001) valikul. Kakskeelse Aksli sõnavara suurenemine pidas igati sammu teiste poiste omaga ja oli tegelikult veelgi kiirem kui näidatud tabelis 3, kui kaasa arvata ka ta ingliskeelne sõnavara (Salasoo 2002a).

Sellest näib, et uute nimisõnade, tegusõnade ja omadussõnade kasutusele võtmise kiirus on võrdlemisi sõltumatu poisse ümbritsevast keelekeskkonnast. Järgnevas vaadeldakse, kuivõrd ühtne või erinev oli poiste omandatud sõnavara.

\section{Poiste sõnavara ühtsus}

Olen nimetanud poistevahelise sõnavara ühtsuseks sõnade arvu, mida kasutasid vähemalt kaks poissi, ja ühtsuse indeksiks ühiste sõnade proportsiooni kõigist sama liiki sõnadest kolme poisi ühises sõnavaras. Need muutujad lubavad võrrelda nii poisse kui ka erinevaid sõnaliike.

Nii näeme tabelis 4, et kõik kolm poissi kasutasid 11 sama omadussõna, mille kohaselt Karl-Oskari ja Lembitu omadussõnade ühtsus kahe teise poisi omadega on $31 \%$ (11 nende 36 omadussõnast) ja Akseli omadussõnade ühtsus kahe 
teise poisi omadega on natuke suurem, 35\% (11 tema 31 omadussõnast).

Needsamad 11 omadussõna moodustasid aga kolme poisi ühisest 64 omadussõnast 17\%, millist indeksit saame võrrelda teiste sõnaliikide omadega. Lisaks kolme poisi ühistele omadussõnadele oli ka omadussõnu, mis olid ühised ainult kahele poisile: neid oli Karl-Oskaril ja Lembitul $5(5,64=8 \%$ ühisleksikonist), Karl-Oskaril ja Akslil 7 (11\%) ning Lembitul ja Akslil jällegi 5 (8\%).

Tabel 4. Ühtsus kolme poisi eestikeelsete omadussõnade vahel

\begin{tabular}{|c|c|c|c|c|c|c|c|c|c|}
\hline Poiss & \multicolumn{3}{|c|}{ Karl-Oskar } & \multicolumn{3}{|c|}{ Lembit } & \multicolumn{3}{|c|}{ Aksel } \\
\hline $\begin{array}{l}\text { Keelekesk } \\
\text { kond }\end{array}$ & \multicolumn{3}{|c|}{ Eesti keel Eetis } & \multicolumn{3}{|c|}{$\begin{array}{l}\text { Peamiselt eesti } \\
\text { keel Austraalias }\end{array}$} & \multicolumn{3}{|c|}{$\begin{array}{l}\text { Eesti ja inglise keel } \\
\text { Austraalias }\end{array}$} \\
\hline $\begin{array}{l}\text { Kasutatud } \\
\text { omadus- } \\
\text { sõnade arv } \\
\text { - kokku } 64\end{array}$ & \multicolumn{3}{|l|}{36} & \multicolumn{3}{|l|}{36} & \multicolumn{3}{|l|}{31} \\
\hline $\begin{array}{l}\text { Ühised } \\
\text { omadussõ } \\
\text { nad }\end{array}$ & Arv & $\begin{array}{l}\text { Ühtsu } \\
\text { indek: } \\
36 \text { st }\end{array}$ & $\begin{array}{l}\text { sse } \\
\text { s } \\
64 \mathrm{st}\end{array}$ & Arv & $\begin{array}{l}\text { Ühtsu } \\
\text { indek } \\
36 \text { st }\end{array}$ & & Arv & $\begin{array}{l}\text { Ühtsus } \\
\text { indeks } \\
\text { 31st }\end{array}$ & $64 \mathrm{st}$ \\
\hline $\begin{array}{l}3 \text { poisil } \\
2 \text { poisil - }\end{array}$ & 11 & $31 \%$ & $17 \%$ & 11 & $31 \%$ & $17 \%$ & 11 & $35 \%$ & $17 \%$ \\
\hline $\begin{array}{l}\text { KO \& L } \\
2 \text { poisil - }\end{array}$ & 5 & $14 \%$ & $8 \%$ & 5 & $14 \%$ & $8 \%$ & - & - & - \\
\hline $\begin{array}{l}\mathrm{KO} \& \mathrm{~A} \\
2 \text { poisil - L }\end{array}$ & 7 & $19 \%$ & $11 \%$ & - & - & - & 7 & $23 \%$ & $11 \%$ \\
\hline$\& A$ & - & - & - & 5 & $14 \%$ & $8 \%$ & 5 & $16 \%$ & $8 \%$ \\
\hline 1 poisil & 13 & $36 \%$ & $20 \%$ & 15 & $41 \%$ & $23 \%$ & 8 & $26 \%$ & $13 \%$ \\
\hline Kokku & 36 & $100 \%$ & $56 \%$ & 36 & $100 \%$ & $56 \%$ & 31 & $100 \%$ & $49 \%$ \\
\hline
\end{tabular}

Varemad uuringud (Salasoo 2005) on näidanud, et ühtsus oli palju väiksem poiste kasutatud nimisõnade vahel (26\% 652 nimisõnast) kui tegusõnade vahel (50\% 139 tegusõnast): pooli tegusõnu ja kolmveerand nimisõnu poiste ühises sõnavaras kasutas ainult üks poistest. Näib (vt tabel 4), et poiste omadussõnade ühtsus $(17 \%+8 \%+11 \%+8 \%=44 \% 64$ omadussõnast) langeb kahe teise sõnaliigi ühtsuse vahele ning $56 \%$ kõigist poiste omadussõnadest kasutati individuaalselt. Olen varem oletanud, et suur vahe nimisõnade ja tegusõnade 
ühtsuse vahel oli põhjustatud nende arvulisest erinevusest poiste ühises lindistusleksikonis, kus nimisõnadest üle nelja korra vähema hulga tegusõnade seast polnud palju valida, nii et neid pidi kordama, mis siis viis suurema poistevahelise ühtsuseni (Salasoo 2005). Tõenäoliselt tuleb ka omadussõnade juures nende arvuline vähesus mängu, kuna neid oli poiste ühisleksikonis veel kaks korda vähem kui tegusõnu. Ent arvatavasti avaldavad mõju ka mingid lisategurid, tingituna omadussõnade sekundaarsusest ja süntaktilisest rollist. Mõned lingvistid (Katz 1964, Bickes 1987) väidavad isegi, et omadussõnade korrektseks kasutamiseks vajalik lingvistiliste võimete hulk tegelikult piirab kasutatavate omadussõnade arvu.

Samas kasutas iga poiss ka omadussõnu, mida teised poisid ei kasutanud. Austraalia poisi Lembitu lindistusleksikonis oli suurim arv selliseid isikupäraseid omadussõnu $(15$, mis on tema 36 sõnast $41 \%$ )(vt tabel 4), kuna ainult ühe poisi kasutatud nimisõnu oli enim Eestis elaval KarlOskaril (60\%) ja enim tegusõnu kakskeelsel Akslil (32\%) (Salasoo 2002b, 2003).

Tabelis 5 näeme aga, et suurearvulisemas poiste ühisleksikonis valitses igas kolmes sõnaliigis küllaltki lähedane ühtlus poiste vahel. Karl-Oskari sõnad olid veidi kõrgema ühtsusega kui Aksli omad (omadussõnade puhul küll samad) ja Lembitu sõnadel oli kõige madalam ühtsus, mis tähendab, et Lembit oli kõige suurem individualist nii nimisõnade, tegusõnade kui ka omadussõnade kasutusele võtmisel.

Tabel 5. Kolme poisi sõnaliikide ühtsusindeks ühises eestikeelses lindistusleksikonis

\begin{tabular}{l|l|l|l} 
Poiss & $\begin{array}{l}\text { Karl- } \\
\text { Oskar }\end{array}$ & Lembit & Aksel \\
\hline Keelekeskkond & $\begin{array}{l}\text { Eesti } \\
\text { keel } \\
\text { Eestis }\end{array}$ & $\begin{array}{l}\text { Peamiselt } \\
\text { eesti keel } \\
\text { Austraalias }\end{array}$ & $\begin{array}{l}\text { Eesti ja } \\
\text { inglise keel } \\
\text { Austraalias }\end{array}$ \\
\hline Nimisõnad -652 & $22 \%$ & $18 \%$ & $20 \%$ \\
\hline Tegusõnad - 139 & $44 \%$ & $36 \%$ & $43 \%$ \\
\hline Omadussõnad -64 & $36 \%$ & $33 \%$ & $36 \%$
\end{tabular}


Sealjuures on aga antud poistevahelised ühtsuse indeksid iga sõnaliigi kohta küllaltki sarnased, et lubada oletada nende üldist representatiivsust eesti keelt omandavate laste suhtes: kõige rohkem kasutatakse samu tegusõnu, millele järgnevad omadussõnad, ja kõige vähem samu nimisõnu.

\section{Esimesed omadussõnad}

Tabelis 6 on kõik poiste omadussõnad (kokku 64) järjestatud vaatlustel esmaesinemise järgi (ilmumisaega märgib poisi vanus). On võimalik, et sõnu tarvitati ka varem, aga siin on kinni peetud vaatlusel registreeritud andmetest. Iga sõna juures on võrdluseks märgitud ka selle esinemiskordade arv täiskasvanute argivestluses (andmed TÜ suulise kõne korpusest). Karl-Oskar ja Lembit kasutasid vaatlustel 36 ning Aksel 31 omadussõna (vt tabel 2). Neist 60 omadussõna esines täiskasvanute keeles.

Esimesed omadussõnad ilmusid kahe noorema poisi kõnesse siis, kui nad mõlemad olid 1 aasta ja 9 kuud vanad (vt tabel 6), mil Karl-Oskar, poiss Eestis, lausus lapsekeelse päh ja Lembit ütles, kuigi valestihääldatuna, lilus 'ilus'. Mõnda aega polnud kuulda teisi omadussõnu, kuid peagi lausus kaheaastane Lembit veel kolm omadussõna: ea 'hea', äike 'väike' ja vana. Ühe kuu võrra vanemana kasutas ka Karl-Oskar sõnu väike ja vana. Kuna kakskeelne Aksel oli tema vaatluse alguses vanem kui teised poisid, ei ole teada, mis olid tema esimesed omadussõnad.

Tabel 6. Poiste vaatluses esimesed eestikeelsed omadussõnad

\begin{tabular}{l|l|l|l|l}
\multirow{2}{*}{$\begin{array}{l}\text { Omadussõn } \\
\text { a }\end{array}$} & \multicolumn{2}{|l|}{ Vanus esmaesinemisel } & $\begin{array}{l}\text { Sagedus } \\
\text { täiskasvanute } \\
\text { argivestluses }\end{array}$ \\
\cline { 2 - 5 } & $\begin{array}{l}\text { Karl- } \\
\text { Oskar }\end{array}$ & Lembit & Aksel & \\
\hline päh 'paha' & $1 ; 9$ & - & - & 11 \\
\hline ilus & $2 ; 4$ & $1 ; 9$ & $3 ; 3$ & 86 \\
\hline hea & $2 ; 6$ & $2 ; 0$ & $3 ; 6$ & 136
\end{tabular}


Laste esimesed eestikeelsed omadussõnad 9

\begin{tabular}{|c|c|c|c|c|}
\hline väike & $2 ; 1$ & $2 ; 0$ & $2 ; 9$ & 110 \\
\hline vana & $2 ; 1$ & $2 ; 0$ & $2 ; 11$ & 63 \\
\hline suur & $2 ; 1$ & $2 ; 4$ & $2 ; 9$ & 103 \\
\hline uus & $2 ; 2$ & $2 ; 4$ & $2 ; 10$ & 67 \\
\hline kallis & $2 ; 2$ & $2 ; 8$ & - & 30 \\
\hline hall & $2 ; 2$ & $3 ; 0$ & - & 4 \\
\hline paha & $2 ; 2$ & $2 ; 10$ & $2 ; 11$ & 6 \\
\hline $\begin{array}{l}\text { taba-aa } \\
\text { 'väike' }\end{array}$ & $2 ; 2$ & - & - & - \\
\hline $\begin{array}{l}\text { täka-täka } \\
\text { 'väike' }\end{array}$ & $2 ; 2$ & - & - & - \\
\hline märg & $3 ; 0$ & $2 ; 3$ & - & 9 \\
\hline raske & - & $2 ; 3$ & $3 ; 5$ & 15 \\
\hline paljas & $2 ; 3$ & - & - & 2 \\
\hline pikk & $2 ; 3$ & - & $2 ; 10$ & 32 \\
\hline kõva & - & $2 ; 4$ & - & 28 \\
\hline hädaohtlik & - & $2 ; 4$ & - & - \\
\hline kena & - & $2 ; 4$ & - & 15 \\
\hline loll & - & $2 ; 4$ & - & 27 \\
\hline magus & - & $2 ; 4$ & - & 1 \\
\hline $\begin{array}{l}\text { must } \\
\text { 'määrdunud' }\end{array}$ & $2 ; 7$ & $2 ; 4$ & - & $\begin{array}{l}\text { (33) } \\
\text { ('värv'/'määr } \\
\text { dunud') }\end{array}$ \\
\hline terav & - & $2 ; 4$ & - & 2 \\
\hline pisi & $2 ; 4$ & - & - & 11 \\
\hline tore & $2 ; 4$ & - & $4 ; 0$ & 26 \\
\hline halb & - & $2 ; 4$ & - & 10 \\
\hline kuiv & - & $2 ; 4$ & - & 4 \\
\hline pime & - & $2 ; 4$ & - & 7 \\
\hline tühi & - & $2 ; 4$ & $2 ; 11$ & 15 \\
\hline kindel & - & $2 ; 5$ & - & 10 \\
\hline
\end{tabular}




\begin{tabular}{|c|c|c|c|c|}
\hline kuum & - & $2 ; 5$ & - & 4 \\
\hline puhas & - & $2 ; 5$ & - & 11 \\
\hline must 'värv' & $2 ; 5$ & $2 ; 5$ & $2 ; 10$ & $\begin{array}{l}\text { (33) } \\
\text { ('värv'/'määr- } \\
\text { dunud') }\end{array}$ \\
\hline kole & $2 ; 5$ & - & $3 ; 1$ & 11 \\
\hline kollane & $2 ; 5$ & $2 ; 5$ & - & 13 \\
\hline valge 'värv' & $2 ; 5$ & $2 ; 10$ & $2 ; 9$ & $\begin{array}{l}(22) \\
\text { ('värv'/' mitte } \\
\text { pime') }\end{array}$ \\
\hline punane & $2 ; 5$ & $3 ; 0$ & $3 ; 1$ & 16 \\
\hline sinine & - & $2 ; 5$ & $2 ; 11$ & 16 \\
\hline sõbralik & - & $2 ; 5$ & - & 1 \\
\hline soe & $2 ; 6$ & $2 ; 7$ & $2 ; 10$ & 18 \\
\hline kuri & $2 ; 6$ & - & $2 ; 11$ & 6 \\
\hline tubli & $2 ; 6$ & - & $2 ; 9$ & 11 \\
\hline valus & $2 ; 6$ & - & - & 3 \\
\hline roheline & - & $2 ; 8$ & $3 ; 1$ & 9 \\
\hline kõrge & $2 ; 9^{\#}$ & - & - & 13 \\
\hline praetud & - & - & $2 ; 9$ & 1 \\
\hline külm & $3 ; 0$ & - & $2 ; 9$ & 28 \\
\hline paks & $2 ; 10^{\#}$ & - & $2 ; 9$ & 14 \\
\hline paras & - & - & $2 ; 10$ & 7 \\
\hline haige & - & $2 ; 10$ & $2 ; 11$ & 21 \\
\hline pruun & - & $2 ; 10$ & - & 9 \\
\hline kiir(e) & - & - & $2 ; 11$ & 11 \\
\hline oranž & - & - & $2 ; 11$ & 1 \\
\hline parem & $2 ; 11$ & - & - & 50 \\
\hline maitsev & $2 ; 11$ & - & - & - \\
\hline hirmus & $2 ; 11$ & - & - & 11 \\
\hline sügav & $2 ; 11$ & - & - & 1 \\
\hline
\end{tabular}




\begin{tabular}{l|l|l|l|l} 
tugev & $2 ; 11$ & - & - & 6 \\
\hline $\begin{array}{l}\text { valge } \\
\text { 'mitte pime' }\end{array}$ & - & - & $2 ; 11$ & $\begin{array}{l}(22) \\
\text { ('värv'/'mitte } \\
\text { pime') }\end{array}$ \\
\hline $\begin{array}{l}\text { kerge } \\
\text { pai }\end{array}$ & - & - & $2 ; 11$ & 6 \\
\hline $\begin{array}{l}\text { imelik } \\
\text { lilla }\end{array}$ & - & - & - & 8 \\
\hline noor & - & - & - & 21 \\
\hline $\begin{array}{l}\text { Eri sõnu } \\
\text { kokku 64 }\end{array}$ & $\mathbf{3 6}$ & $\mathbf{3 6}$ & $3 ; 1$ & 1 \\
\hline
\end{tabular}

\# ei esinenud lindistustes

Näib, et poiste esmaste omadussõnade tagavara oli väga sarnane: üheteistkümnest kõigile ühisest omadussõnast seitse (ilus, hea, väike, vana, suur, uus ja paha) ilmusid Lembitu ja Karl-Oskari lindistusleksikonidesse üsna varakult, kuna poiste ülejäänud neli ühist omadussõna (värvid must, valge ja punane ning temperatuurisõna soe) tulid kasutusele hiljem. See lubab järeldada, et arvatavasti paljud eesti keelt kõnelevad väikesed lapsed alustavad oma nimisõnade täpsustamist, nimetades neid ilusaks, heaks ja pahaks, väikeseks ja suureks, vanaks ja uueks.

Individuaalselt kasutatavate omadussõnade arv aga suurenes peatselt. Tabelis 6 näeme, et suurem osa Lembitu omadussõnu, milliseid ta 2 aasta ja 4 kuu vanuselt esmalt väljendas, ei ilmunudki teiste poiste lindistustesse. Samuti kasutasid teised poisid väga väheseid neist Karl-Oskari omadussõnadest, mis ilmusid pärast seda, kui ta oli kaks ja pool aastat vana.

Ilmselt omadussõnade ühtsus ei ole konstantne, vaid muutub aja jooksul, olles alul kolme poisi vahel kõrge, kuid kui lühikese aja jooksul on hädavajalikud sõnad omandatud, siis näib ühtsus poiste vanemaks saades kiiresti vähenevat ja isikupäraste sõnade kasutuselevõtt sagenevat. Aja jooksul koguneb aga pidevalt poiste leksikonidesse ka samu sõnu, mis sõnade üldarvu kohta võivad küllaltki kõrge ühtsusindeksi anda. 


\subsection{Võrdlus inglise keelt omandavate laste omadussõnadega}

Kas tähelepanekud eestikeelsete esmalt kasutatud omadussõnade kohta kehtivad ka teiste keelte suhtes? Kahjuks ei olnud üldiselt kasutatud lastekeele sõnavara mõõtmise instrument - Lapse esimesed 50 sõna (MacArthur Communicative Development Inventory (CDI), Fenson 1994, 93-92) - eesti poiste ja Ameerikas inglise keelt omandavate laste omadussõnade võrdlemiseks sobiv, kuna siin vaadeldud mõlema noorema poisi esimese 50 lindistatud sõna hulgas oli ainult üks omadussõna. Sobivama võrdluse võimaldasid 669 briti 1;0-2;1-aastase lapse 39 omadussõna (Oxford Communicative Inventory, Hamilton jt 2000), millest nähtus, et selleks ajaks, kui sõnaomandamise algusest peale vaadeldud poiste Karl-Oskari ja Lembitu vanus oli 2;1, oli nende ühisleksikonis kuus omadussõna (päh (paha), hea, suur, ilus, väike, vana), mis kõik ühtisid briti laste ingliskeelsete mõistetega. Nii võib neid mõisteid mõlema keele, võibolla isegi universaalseteks esimesteks nimisõnade täpsustajateks pidada.

Aja jooksul hakkasid eesti poisid ikka rohkem ja rohkem inglise keelt omandavate lastega samatähenduselisi omadussõnu kasutama, kuni vaatlusperioodi lõpul, mil eesti poisid olid kolm (Aksel neli) aastat vanad, oli neil kasutusel juba 26 inglise lastega mõisteliselt ühtivat omadussõna (must (määrdunud), külm, märg, kuum, puhas, punane, pime, sinine, tühi, kollane, kena, roheline, hea, suur, ilus, valus, haige, väike, kiire, kuiv, paha, vana, kõva, raske, kole ja uus), mis andis eesti ja inglise laste ühtsusindeksiks $67 \%$. Kui veel meenutada, et poistel võis ju veelgi rohkem omandatud omadussõnu olla, millised ei juhtunud esinema nende lindistusleksikonides, siis võis ühtsus eesti- ja ingliskeelsete omadussõnade vahel veelgi suurem olla. Selle kohaselt võib oletada, et vaadeldud eesti poiste kasutatud omadussõnade mõisted on küllaltki sarnased inglise keelt ja võibolla ka siis teisi keeli omandavate laste omadega. 


\subsection{Vastanduvad paarid}

Kuus poiste ühisest seitsmest varajasest omadussõnast kuulus antonüümipaaridesse (hea-paha, väike-suur, vana-uus), mis viitab sellele, et lapsed olid selleks ajaks juba mõistma hakanud kontrasti printsiipi. Natuke hiljem lisandusid kõigi kolme sõnavarasse veel vastandid must ja valge ja hiljem veel kuum või soe ja külm (vt tabel 6).

Ei saa öelda, et esilduvamat osa paarist oleks alati kasutatud varem (vt Argus, Podneks 2007). Näiteks Karl-Oskar kasutas sõna ilus varem kui kole ja hirmus ning soe varem kui külm, Lembit kasutas omadust hea palju varem kui halb ja paha ning väike varem kui suur ning Aksel kasutas värvinimetust valge varem kui must ja kerge varem kui raske. Need nähtused ühtivad rohkem Eve Clark'i (1973) väitega inglise keele kohta, et antonüümsetest omadussõnapaaridest omandatakse varases lapsekeeles varem markeerimata pool. Kuid poistel oli ka selliseid paare, kus negatiivsem pool tuli kasutusele varem.

Hilisemas raamatus täpsustab E. Clark (1993: 32), et dimensioonide suhtes peetakse skaala positiivset otsa markeerimatuks. Ta väidab, et paar suur-väike omandatakse esmalt, millele järgnevad positiivsed omadussõnad teiste dimensioonide jaoks. Karl-Oskari omadussõnad näivad järgivat sama skeemi (vt tabel 6): kui ta oli 2 aastat ja 1 kuu vana, ilmus lindistusse sõnapaar väike-suur, millele järgnesid pikk (vanuses $2 ; 3)$, kõrge (2;9) ja sügav (2;11), kuna nende vastandeid (lühike ja madal) ta ei kasutanud. Lembit kasutas vaid paari väike-suur, kuid Akslil esines ka dimensioon pikk. E. Clark väidab, et selline asümmeetria sõnade omandamisel pärineb juba mõistelise skaala kujunemisest.

\subsection{Hinnanguid tähistavad omadussõnad}

Poiste kasutatud 64 eri omadussõnast olid ligi pooled (47\%) seotud hinnangutega, millest 15 olid positiivsed ja 15 negatiivsed (vt tabel 7). Positiivsetest sõnadest kasutas kolm poissi sõnu ilus, hea, väike (hellitlevalt) ja soe, kahe poisi leksikoni ilmusid kallis, tore ja tubli ning sõnu kena, magus, 
puhas, sõbralik, kiir(e), parem, maitsev ja pai võis kuulda ühe poisi suust. Negatiivse kaastähendusega sõnadest kasutasid sõna paha kõik poisid, sõnad kole, kuri, külm, paks ja haige olid kasutusel kahel poisil ning sõnu päh, raske, hädaohtlik, loll, halb, kuum, valus ja hirmus kasutas ainult üks poiss.

Arvuline võrdsus positiivse ja negatiivse tähendusega omadussõnade vahel tabelis 7 erineb E. Clarki nimetatud (1993: 32) tavaliselt esinevast positiivsete sõnade suuremast arvust. Vaadeldud poiste (ja ka täiskasvanute) tulemuste sarnasus paneb kaaluma, kas see pole eesti keele või eestlaste hoiaku iseärasus.

Tabel 7. Poiste ja täiskasvanute hinnanguid tähistavad eestikeelsed omadussõnad

\begin{tabular}{l|l|l|l|l|l} 
& $\begin{array}{l}\text { Arv poistel } \\
\text { Karl- } \\
\text { Oskar }\end{array}$ & Lembit & Aksel & $\begin{array}{l}\text { Ühisleksi- } \\
\text { konis }\end{array}$ & $\begin{array}{l}\text { Arvask } \\
\text { täiskasv } \\
\text { anutel }\end{array}$ \\
\hline Üldarv & 36 & 36 & 31 & 64 & 457 \\
\hline Positiivsed & 9 & 9 & 6 & 15 & 129 \\
\hline $\begin{array}{l}\text { Negatiivsed } \\
\text { Kokku }\end{array}$ & 9 & 8 & 7 & 15 & 109 \\
\hline $\begin{array}{l}\text { Suhe üld- } \\
\text { arvust }\end{array}$ & $50 \%$ & 17 & 13 & 30 & 238 \\
\hline
\end{tabular}

\section{Võrdlus täiskasvanute keelekasutusega}

Et jõuda arusaamisele, kuidas suhestub kahe väljaspool Eestit kasvava lapse keeleline areng tavapärases eesti keskkonnas sirguva lapse omaga, valisin oma uuringu üheks subjektiks, n-ö kontrolliks Karl-Oskari. Lisaküsimusele, kuidas lähenes laste leksikaalne areng tavalisele kõnekeelele Eestis, vastuste leidmiseks otsustasin võrrelda laste andmeid Eestis elavate täiskasvanute omadega, seekord omadussõnadega (vt tabelid 6 ja 7). Tartu Ülikooli kõnekeele uurimisgrupilt sain tavalise kõnekeele korpuse, mille 14091 erineva sõna hulgast leidsin 457 omadussõna, mida võrdlesin nii poiste isiklike kui 
ka nende ühise 64 omadussõnaga. Kuigi mind võidakse süüdistada õunte ja apelsinide võrdlemises, väidan siiski, et mõlemad näitajad: poiste vanus, kui esimest korda märgati mõnd sõna, ja täiskasvanute kasutamissagedus annavad teatud aluse mõne omadussõna tähtsuse võrdluseks.

\subsection{Täiskasvanute omadussõnade kasutamis- sagedus}

Tabelis 8 näeme täiskasvanute omadussõnade kasutamissageduse analüüsi tulemusi. Ilmnes, et suurem osa (84\% ehk 384 sõna) täiskasvanute 457 omadussõnast esines korpuses väga harva, vähem kui 10 korda. Väiksem osa (16\% ehk 73 sõna) esines korpuses kümme või enam korda. Täiskasvanute kõige sagedam omadussõna hea esines 136 korda, kuues erinevas vormis. Kuid ainult kolme omadussõna (hea, väike, suur) kasutati rohkem kui 100 korda.

Tabel 8. Eestikeelete omadussõnade sagedus täiskasvanute ja arv poiste kõnes

\begin{tabular}{|c|c|c|c|c|}
\hline \multicolumn{2}{|c|}{ Täiskasvanute omadussõnad } & \multirow{3}{*}{\begin{tabular}{r|}
.1 .1 \\
.1 .2 \\
.1 .3
\end{tabular}} & \multirow{2}{*}{\multicolumn{2}{|c|}{$\begin{array}{l}\text { Poiste } \\
\text { omadussõnad } \\
\text { Arv - kokku } 64\end{array}$}} \\
\hline \multirow[t]{2}{*}{ Arv - kokku 457} & \multirow[t]{2}{*}{ Sagedus } & & & \\
\hline & & & Lembit & Aksel \\
\hline hea, väike, suur (kokku 3) & $136-103$ & 3 & 3 & 3 \\
\hline $\begin{array}{l}\text { ilus, uus, vana, parem } \\
\text { (kokku 4) }\end{array}$ & $86-50$ & 4 & 3 & 3 \\
\hline $\begin{array}{l}\text { enam, esimene } \\
\text { (kokku 3) }\end{array}$ & $78-52$ & - & - & - \\
\hline $\begin{array}{l}\text { huvitav, ôige, igasugune } \\
\text { jube, odav, järgmine, } \\
\text { eelmine, terve (kokku 8) }\end{array}$ & $45-28$ & - & - & - \\
\hline $\begin{array}{l}\text { must 'värv', must } \\
\text { 'määrdunud', pikk, kallis, } \\
\text { noor, kõva, külm, loll, tore } \\
\text { (kokku 9) }\end{array}$ & $33-26$ & 6 & 5 & 5 \\
\hline
\end{tabular}




\begin{tabular}{|c|c|c|c|c|}
\hline $\begin{array}{l}\text { hull, viimane, lahe, tuttav, } \\
\text { jôle, naljakas, mõnus, } \\
\text { normaalne, tark, kihvt, } \\
\text { lihtne, vaba, erinev, julge, } \\
\text { selge, vaene, libe, surnud, } \\
\text { tähtis, tõsine, võimalik, } \\
\text { maru, varem, vihane } \\
\text { (kokku 24) }\end{array}$ & $24-10$ & - & - & - \\
\hline $\begin{array}{l}\text { valge 'värv', valge 'hele', } \\
\text { soe, haige, imelik, kollane, } \\
\text { punane, päh, raske, kena, } \\
\text { tühi, paks, kiire, kõrge, } \\
\text { pisike, puhas, sinine, kole, } \\
\text { tubli, hirmus, halb, kindel } \\
\text { (kokku 22) }\end{array}$ & $22-10$ & 11 & 13 & 12 \\
\hline $\begin{array}{l}\text { Kokku rohkem kui } 10 \\
\text { korda kasutatud sõna } \\
-73(16 \% 457 \mathrm{st})\end{array}$ & $136-10$ & 24 & 24 & 23 \\
\hline 6 sõna & 9 & 1 & 3 & 1 \\
\hline 6 sõna & 8 & 1 & & - \\
\hline 10 sõna & 7 & - & 1 & 1 \\
\hline 18 sõna & 6 & 3 & 1 & 3 \\
\hline 13 sõna & 5 & - & - & - \\
\hline 33 sõna & 4 & 1 & 3 & - \\
\hline 33 sõna & 3 & 1 & - & - \\
\hline 80 sõna & 2 & 1 & 1 & - \\
\hline 185 sõna & 1 & 1 & 2 & 3 \\
\hline $\begin{array}{l}\text { Kokku vähem kui } 10 \\
\text { korda kasutatud sõna } \\
-384(84 \% \text { 457st })\end{array}$ & $9-1$ & 9 & 11 & 8 \\
\hline $\begin{array}{l}\text { Täiskasvanutel } \\
\text { puuduvad sõnad }\end{array}$ & & 3 & 1 & 0 \\
\hline KOGUSUMMA 457 & $1-136$ & 36 & 36 & 31 \\
\hline
\end{tabular}




\section{2. Ühtsuse indeksid poiste ja täiskasvanute omadussõnade vahel}

Suurem osa poiste esimestest omadussõnadest (kokku 64) oli kasutuses ka täiskasvanutel (vt tabel 6). Täpsemalt, 60 omadussõna olid käibel täiskasvanutel ja vähemalt ühel poisil. See moodustab $94 \%$ poiste omadussõnadest. Poiste omadussõnadest puudus täiskasvanute korpuses vaid neli: tabaaa, taka-taka, maitsev ja hädaohtlik. Esimesed kaks olid KarlOskari isikupärased lapsekõne sõnad vanuses $2 ; 2$, mõlemad tähenduses 'väike', ja maitsev oli Karl-Oskari peaaegu kolmeaastasena öeldud päris täiskasvanulik sõna. Sõna hädaohtlik kasutas 2 aasta ja 4 kuu vanune Lembit päris tihti. Täiskasvanutel esines küll sõna ohtlik, aga seegi ainult kaks korda. Kõik Aksli omadussõnad esinesid ka täiskasvanutel.

Poiste omadussõnade kõrge 94\%-line ühtsus täiskasvanute omadussõnadega vastandub teravalt täiskasvanute omadussõnade madala ühtsusega poiste omadussõnadega. Vaadeldud kolm poissi kasutasid oma kolmanda eluaasta lõpul kokku ainult 60 (13\%) täiskasvanute 457 omadussõnast. See oli palju madalam kui poiste omavahelised ühtsuse indeksid, mis olid $58 \%$ ja $74 \%$ vahel (vt tabel 9).

Selline madal ühtsuse indeks on arvatavasti osaliselt põhjustatud paljude täiskasvanute omadussõnade madalast sagedusest, mille kohaselt ainult 73 omadussõna kasutati kümme või enam korda (vt tabel 8). Võib arvata, et paljusid täiskasvanute omadussõnu kuuleb nii harva, et lastel pole lihtsalt küllalt võimalusi nende varaseks omandamiseks.

Vaadeldes lähemalt tabelit 6 näeme, et $22(37 \%)$ nendest 60 omadussõnast, mis esinesid nii poistel kui ka täiskasvanutel, kasutasid täiskasvanud vähem kui kümme korda. Kui jätta kõrvale need vähekasutatud täiskasvanute omadussõnad poistega ühtsuse arvestamisel, jätaks see 38 poiste ja täiskasvanute ühist omadussõna. Selle alusel arvutatud täiskasvanute ühtsus poistega $(38 / 73=52 \%)$ läheneb poiste omavahelisele ühtsusele (58-74\%). Mõlemad need võimalused on näha tabelis 9 , mis koondab andmeid teistest tabelitest. 
Tabel 9. Poiste ja täiskasvanute eestikeelsete omadussõnade vahelise ühtsuse indeksid

\begin{tabular}{|c|c|c|c|c|c|}
\hline \multicolumn{2}{|l|}{ Poisid } & $\begin{array}{l}\text { Karl- } \\
\text { Oskar }\end{array}$ & Lembit & Aksel & $\begin{array}{l}\text { Poisid } \\
\text { kokku }\end{array}$ \\
\hline \multicolumn{2}{|c|}{ Omadussõnade arv } & 36 & 36 & 31 & 64 \\
\hline \multicolumn{2}{|c|}{$\begin{array}{l}\text { Poiste ühtsus teiste } \\
\text { poistega }\end{array}$} & $\begin{array}{l}23 / 36 \\
64 \%\end{array}$ & $\begin{array}{l}21 / 36 \\
58 \%\end{array}$ & $\begin{array}{l}23 / 31 \\
74 \%\end{array}$ & \\
\hline \multirow{2}{*}{$\begin{array}{l}\text { Poiste } \\
\text { ühtsus } \\
\text { täiskasva } \\
\text { nutega }\end{array}$} & $\begin{array}{l}\text { Kõigi } \\
\text { omadus- } \\
\text { sõnadega }\end{array}$ & $\begin{array}{l}33 / 36 \\
92 \%\end{array}$ & $\begin{array}{l}35 / 36 \\
97 \%\end{array}$ & $\begin{array}{l}31 / 31 \\
100 \%\end{array}$ & $\begin{array}{l}60 / 64 \\
94 \%\end{array}$ \\
\hline & $\begin{array}{l}\text { 10+ korda } \\
\text { kasutatute } \\
\text { ga }\end{array}$ & $\begin{array}{l}24 / 36 \\
67 \%\end{array}$ & $\begin{array}{l}24 / 36 \\
67 \%\end{array}$ & $\begin{array}{l}23 / 31 \\
74 \%\end{array}$ & $\begin{array}{l}38 / 64 \\
59 \%\end{array}$ \\
\hline \multirow{2}{*}{$\begin{array}{l}\text { Täiskasv } \\
\text { anute } \\
\text { ühtsus } \\
\text { poistega }\end{array}$} & $\begin{array}{l}\text { Kõigi } \\
\text { omadus- } \\
\text { sõnadega }\end{array}$ & $\begin{array}{l}33 / 45 \\
77 \%\end{array}$ & $\begin{array}{l}35 / 45 \\
78 \%\end{array}$ & $\begin{array}{l}31 / 45 \\
77 \%\end{array}$ & $\begin{array}{l}0 / 45 \\
73 \%\end{array}$ \\
\hline & $\begin{array}{l}10+\text { korda } \\
\text { kasutatute } \\
\text { ga }\end{array}$ & $\begin{array}{l}24 / 73 \\
33 \%\end{array}$ & $\begin{array}{l}24 / 73 \\
33 \%\end{array}$ & $\begin{array}{l}23 / 73 \\
32 \%\end{array}$ & $\begin{array}{l}38 / 75 \\
32 \%\end{array}$ \\
\hline
\end{tabular}

Tabeli 9 selgituseks võib vaadelda selles Karl-Oskari andmeid. Karl-Oskari 36 omadussõnast 23 (64\%) esineb ka teiste poiste lindistusleksikonides (vt tabel 4), kuna täiskasvanute keeles esineb neist 33 (92\%) (vt tabel 6). Need 33 Karl-Oskari omadussõna, mis leidusid ka täiskasvanute korpuses, moodustasid ainult 7\% täiskasvanute 457 omadussõnast. Seevastu 24 Karl-Oskari (nagu ka Lembitu) omadussõna, mis ühtisid täiskasvanute sagedama sõnavaraga (73 sõna), moodustasid nendest 33\%. Kui meenutada, et kuigi täiskasvanute omadussõnade hulgas oli vaid $16 \%$ omadussõnu, mida kasutati kümme või rohkem korda (vt tabel 8), siis moodustasid need sagedasti kasutatud täiskasvanute omadussõnad $67-74 \%$ poiste individuaalsetest omadussõnade leksikonidest ja $59 \%$ poiste ühisest omadussõnade leksikonist. See viitab jällegi, et lapsed omandavad sageli kuuldud keelendeid kas varem või kergemini kui harva kuulduid.

Austraalias elunevad poisid olid ühtsuse skaala vastasotstel (vt tabel 9). Kakskeelne Aksel demonstreeris kõige 
suuremat ühtsust, sest tal oli kõige rohkem omadussõnu (74\%), mis ühtisid nii teiste poiste kui ka täiskasvanute sageli kasutatud omadussõnadega. Lembit aga demonstreeris oma suurimat individuaalsust madalaimate ühtsusindeksitega nii teiste poiste omadussõnadega $(58 \%)$ kui ka täiskasvanute omadega $(67 \%)$. Poiss Eestis, Karl-Oskar, kellest oleks oodanud kõige suuremat ühtsust täiskasvanutega, jäi selles suhtes võrdseks Lembituga ning poiste omavahelises ühtsuses keskmiseks. Selline tulemus võis olla põhjustatud poiste individuaalsetest erivõimetest või siis nende kõnepartnerite spetsiifilisest keelelisest sisestusest.

Peamine järeldus ühtsusanalüüsi tulemustest on siiski, et kolme vaadeldud poisi algne omadussõnade kasutus oli võrdlemisi lähedal Eestis elavate täiskasvanute tavalisele kõnekeelele, mille sagedamini kasutatavatest omadussõnadest ühtis üks kolmandik poiste individuaalselt kasutatud omadussõnadega ja pool poiste omadussõnade ühisleksikoniga. Nende mõõdete sarnasus poiste vahel viitab aga jällegi erinevate keelekeskkondade mõju vähesusele.

\subsection{Sisulised erinevused poiste ja täiskasvanute vahel}

Täiskasvanute omadussõnad, mida väikesed poisid ei kasutanud, viitavad tähenduse olulisusele sõnade omandamisel. Tabelis 8 on näidatud kõik 73 omadussõna, mida täiskasvanud kasutasid rohkem kui üheksa korda, samuti ka, kui palju neist esines laste lindistusleksikonides. Poolt (35) neist sagedastest omadussõnadest poisid ei kasutanud. Kõige sagedamini esinevad neli täiskasvanute omadussõna hea (136 korda), väike (110), suur (103) ja ilus (86) olid ilmselt lisaks sagedale kasutusele ka lapsele tähendusrikkad ning ilmusid varakult kõigi kolme poisi sõnavarasse (vt tabel 6). Sageduselt järgmised täiskasvanute omadussõnad enam (kasutatud 78 korda ) ja esimene (71) olid abstraktsema tähendusega, mida lapsel arvatavasti eriti vaja poleks, ja nii vaadeldud poisid neid ei kasutanud, nagu ka mitte võrdlemisi ebamääraseid, mittelapsepäraseid sõnu järgmine, eelmine, viimane, normaalne, võimalik jne. Lapsel on arvatavasti vaja rohkem 
aega selliste mõistete tekkimiseks ja siis vastavate omadussõnade kasutamiseks. Tõenäoliselt ei kasutanud ka vaadeldud poistega suhtlejad selliseid sõnu.

Näib, et omadussõnade, nii kui teistegi sõnade omandamisel on üheks määravaks teguriks ka tähendus. Laps omandab esijoones selliseid sõnu, millega ta oskab end seostada ja millist mõistet kujundada.

\section{Kokkuvõtteks}

Selle uurimuse tulemused näitavad kolme eri tingimustes eesti keelt omandava väikese poisi kohta järgmist.

Uued eestikeelsed sõnad ilmuvad poiste kõnesse eri kiirustega, vastavalt sõnaliigile: omadussõnad kuni 10 korda aeglasemalt kui nimisõnad ning umbes 2-3 korda aeglasemalt kui tegusõnad. Seetõttu on neid poiste lindistusleksikonides ka vähem kui nimi- ja tegusõnu. Kiirus, millega lapsed uusi omadussõnu kasutama hakkavad, nii nagu nimi- ja tegusõnadegi oma, näib olevat sõltumatu lapse makrokeskkonnast, nagu elamine eesti- või ingliskeelsel maal, kas ainult eesti keeles või kahes keeles kõnetamine, kas emakeelena või võõrkeelena eesti keelt või üldse mitte eesti keelt kõneleva vanema omamine (niikaua kui lapse hooldajaks on ka keegi temaga sageli eesti keelt kõnelev isik). Uute sõnade kasutamise kiirus näib olevat mõjutatud ka lapse individuaalsetest lingvistilistest võimetest.

Erinevates kasvutingimustes eesti keelt omandavad lapsed kasutavad küllaltki palju samu sõnu, mida artiklis on nimetatud nende (vaatlus)leksikonides esinevate sõnade ühtsuseks. Kuigi poistevahelised ühtsusindeksid ei olnud identsed, olid nad siiski igas sõnaliigis küllalt sarnased, et oletada nende üldist representatiivsust eesti keelt omandavate laste suhtes: kõige rohkem kasutatakse samu tegusõnu (pooled ühisleksikonis), millele järgnevad omadussõnad (44\% ühisleksikonis), ja kõige vähem samu nimisõnu (veerand ühisleksikonis).

Poiste nimi- ja tegusõnade ühtsuse pöördvõrdelisust nende arvuga võiks seletada nii: mida rohkem sõnu, seda väiksem ühtsus, kuna valikut on rohkem. Kuid vaatamata kõige 
väiksemale sõnade arvule ei olnud omadussõnade ühtsus kõige kõrgem, vaid jäi hoopis nimi- ja tegusõnade ühtsuse vahele, arvatavasti mõjutatuna sellistest lisateguritest nagu omadussõnade sekundaarsus ja süntaktiline roll.

Omadussõnade ühtsus ei olnud konstantne, vaid nende esialgne ühtsus kolme poisi vahel näis poiste vanemaks saades kiiresti vähenevat ja isikupäraste sõnade kasutuselevõtt sagenevat. Kuigi vahe poiste isikupäraste sõnade kasutuses polnud statistiliselt oluline, ilmnes, et poiss Austraalias, Lembit, oli kõige suurem individualist nii nimisõnade, tegusõnade kui ka omadussõnade kasutuselevõtmisel.

Arvatavasti alustavad kõik eesti keelt kõnelevad väikesed lapsed, nagu vaadeldud poisidki, oma nimisõnade täpsustamist, nimetades neid ilusaks, heaks ja pahaks, väikeseks ja suureks, vanaks ja uueks.

Samuti ilmuvad laste kõnesse varakult eestikeelsed antonüümsed omadussõnade paarid ning hinnangulised omadussõnad. Ligi pooled poiste kasutatud omadussõnadest väljendasid hinnanguid, mis jagunesid omakorda pooleks positiivsete ja negatiivsetena. Kuna selline arvuline võrdsus erineb inglise keeles tavaliselt esinevast positiivsete sõnade suuremast arvust, siis paneb vaadeldud poiste (ja ka täiskasvanute) tulemuste sarnasus kaaluma, kas see pole eesti keele või eestlaste hoiaku iseärasus.

Kuna eesti keelt omandavate poiste omadussõnade ühtsusindeks briti laste samasuguseid omadusi tähistavate mõistetega oli $67 \%$, siis võib öelda, et vaadeldud eesti poiste kasutatud omadussõnade mõisted on küllaltki sarnased inglise keelt, ja võib-olla ka siis teisi keeli omandavate laste omadega.

Poiste omadussõnade eriti kõrge ühtsus täiskasvanute omadussõnadega ja vastupidine, täiskasvanute omadussõnade madal ühtsus poiste omadega on arvatavasti tingitud sellest, et enamikku täiskasvanute omadussõnadest $(84 \%$ korpuses esinevatest) kasutatakse harva ja nii ei ole lastel võimalust neid palju kuulda. Omadussõnade harv esinemine näitab muidugi ka, et neid pole palju vaja. Asjaolu, et $67-74 \%$ poiste individuaalsetest omadussõnadest olid ühised täiskasvanute sagedasti kasutatud omadussõnadega, viitab jällegi, et lapsed omandavad sageli kuuldud keelendeid kas varem või kergemini kui harvakuulduid. 
Samas aga illustreerisid täiskasvanute sageli esinevad omadussõnad, mida poisid ei kasutanud, kuidas tähendus tihti mõjutab ja võib isegi isegi ületada sageduse mõju, nii et laps omandab esmajärgus need paljukuuldud sõnad, millest ta aru saab ja mis seostuvad millegi temale olulisega.

Aksli kõige kõrgemad ja Lembitu kõige madalamad ühtsusindeksid nii teiste poiste kui täiskasvanute sageli esinevate omadussõnadega, samuti ootustevastane Eestis elava Karl-Oskari madalaim ühtsusindeks täiskasvanute omadussõnadega võisid olla põhjustatud poiste individuaalsetest võimetest või siis nende kõnepartnerite sisendkeelest (mida artiklis ei vaadeldud).

Peamine järeldus ühtsusanalüüsi tulemustest on siiski, et vaadeldud kolme poisi esimesed omadussõnad olid võrdlemisi lähedased Eestis elavate täiskasvanute kõnekeelele, mille sagedamini kasutatavatest omadussõnadest ühtis üks kolmandik poiste individuaalselt kasutatud omadussõnadega ja pool poiste omadussõnade ühisleksikoniga. Nende mõõdete sarnasus viitab jällegi poiste erinevate keelekeskkondade mõju vähesusele.

\author{
Aadress: \\ Tiiu Salasoo \\ Director Estonian Learning Materials \\ 13/288 Pacific Hwy \\ Artarmon 2064 \\ Australia \\ E-mail: salasoo@ihug.com.au
}

\title{
Kirjandus
}

Argus, Reili ja Pilleriin Podneks (2007) „Adjektiivide omandamisest eesti keeles“. Ettekanne VI rakenduslingvistika konverentsil „Keel ja leksikon“, 26.-27.4.2007, Tallinn.

Bickes, Gerhard (1987) "On the role of adjectives in the language acquisition of adult immigrants in Germany". Paper presented at 8th World Conference of Applied Linguistics, Sydney, Australia, August 16-21, 1987. 
Blackwell, Aleka A. (2005) "Acquiring the English adjective lexicon: relationships with input properties and adjectival semantic typology". Journal of Child Language 32, 535-562.

Chomsky, Noam (1959) "Review of B. F. Skinner, Verbal behaviour". Language 35, 26-58.

Chomsky, Noam (1976) Aspects of the theory of syntax. Cambridge, Mass.: The M.I.T. Press.

Clark, Eve V. (1973) "What's in a word? On the child's acquisition of semantics in his first language". In T. E. Moore, ed. Cognitive development and the acquisition of language. New York: Academic Press, 65-110.

Clark, Eve V. (1993) The lexicon in acquisition. (Cambridge Studies in Linguistics, 65.) Cambridge: Cambridge University Press.

EKSS = Eesti kirjakeele seletussõnaraamat. I-VII. (1988-2007) Tallinn: Eesti Keele Instituut.

Erelt, Mati, Tiiu Erelt ja Kristiina Ross (1997) Eesti keele käsiraamat. Tallinn: Eesti Keele Sihtasutus.

Fenson, L., P. Dale, P. Reznick, E. Bates, D.Thal, and J. Pethick (1994) Variability in early communicative development. Monographs of the Society for Research in Child Development, Vol. 59, No. 5, 1-173.

Flynn, Valerie, Elise Masur, Frank Eichorst, and Doreen L. Eichorst (2004) "Opportunity versus disposition as predictors of infants' and mothers' verbal and action imitation". Infant Behavior and Development 27, 3, 303-314

Hamilton, A., K. Plunkett and G. Schafer (2000) "Infant vocabulary development assessed with a British Communicative Development Inventory: Lower scores in the UK than the USA". Journal of Child Language 27, 689-705.

Kaalep, Heiki-Jaan ja Kadri Muischnek (2002) Eesti kirjakeele sagedussõnastik. Tartu: Tartu Ülikooli Kirjastus.

Katz, J. J. (1964) "Semantic theory and the meaning of good". The Journal of Philosophy 61, 816-837.

Naigles, L. R. and E. Hoff-Ginsberg (1998) "Why are some verbs learned before other verbs? Effects of input frequency and structure on children's early verb use". Journal of Child Language 25, 1, 95- 120.

Ninio, Anat (1999) "Model learning in syntactic development: Intransitive verbs". International Journal of Bilingualism 3, 133-182.

Salasoo, Tiiu (1995) „Morfoloogiliste tunnuste esmakasutamine ühe lapse arenevas keeles“. Keel ja Kirjandus 4, 239-252.

Salasoo, Tiiu (1996) "Observations in the natural acquisition of Estonian morphology: A mix-and-match of stems and suffixes". In Maisa Martin and Pirkko Muikku-Werner, eds. Finnish and Estonian: New Target Languages. Proceedings of the Fenno-Ugric Languages as Second and Foreign Languages Symposium. Congressus Octavus 
Internationalis Fenno-Ugristarum 10.-15.8.1995. Centre for Applied Language Studies. Jyväskylä: University of Jyväskylä, 86-115.

Salasoo, Tiiu (1998a) "Same goal in three settings: early acquisition of Estonian in native monolingual, non-native monolingual and bilingual environments". Paper at the XVI International Congress of Linguistics at Paris, France, 20.-25.7.1997. CD-ROM on the conference, 147, so7, 24. Elsevier.

Salasoo, Tiiu (1998b) „Esimene isik Austraalia kakskeelse lapse arenevas keeles“. Liina Lindstöm, toim. Väliseestlaste keelest, 81-100. (Tartu Ülikooli eesti keele õppetooli toimetised, 9.) Tartu: Tartu Ülikool.

Salasoo, Tiiu (1999) "Initial acquisition patterns of Estonian and language curriculum design". In Emma H. Santos Castillo, ed. Educating via Language, 64-76. Language Education Council of the Philippines \& Language Study and Research Center, Inc., Manila.

Salasoo, Tiiu (2001) "How do children manage to learn Estonian? Initial acquisition". Redegit Tõnu Seilenthal, curaverunt Anu Nurk, Triinu Palo. Congressus nonus internationalis fenno-ugristarum, 7.13.8.2000, Tartu. Pars VI. Dissertationes sectionum: linguistica. III, 122-132. Tartu.

Salasoo, Tiiu (2002a) "Use of initial Estonian and English verb forms by a bilingual child". Liina Lindström ja Oksana Palikova, toim. Emakeel ja teised keeled III, 181-206. (Tartu Ülikooli eesti keele (võoorkeelena) õppetooli toimetised, 1.) Tartu: Tartu Ülikool.

Salasoo, Tiiu (2002b) "What actions do children learning Estonian talk about?" Proceedings of the XIII Conference of the Finno-Ugric Studies Association of Canada, April 26-28, 2002, 45-60. Burnaby: Simon Fraser University.

Salasoo, Tiiu (2003a) "The early nouns - What do children learning Estonian talk about?" E. Hajicova, A. Kotesovcova, J. Mirovsky (eds). Proceedings of CIL17, July 24-29, 2003. CD-ROM. Matfyzpress, MFF UK. Prague.

Salasoo,Tiiu (2003b) "A step in the search for an explanation of the acquisition of Estonian". Helle Metslang and Mart Rannut, eds. Languages in development, 149-166. (Linguistics Edition, 41.) München: Lincom Europa.

Salasoo, Tiiu (2005) "The initial vocabulary of children learning Estonian What do they talk about?" Congressus decimus internationalis fennougristarum, Yoshkar-Ola, August 16-20, 2005. Summaria acroasium in sectionibus. Pars II. Linguistica, 225-227. Yoshkar-Ola. [Ilmumas.]

Salasoo, Tiiu (2006) "Marking Estonian Substantives - how does it start?" Paper presented at the Fifteenth Conference of the Finno-Ugric Studies Association of Canada, 29-30 May, 2006 at York University in Toronto. [Ilmumas.] 
Laste esimesed eestikeelsed omadussõnad 25

TÜ suulise kõne uurimisrühm (2007) Suulise kõne korpus, vt http://www.cl.ut.ee/suuline/Korpus.php (20.02.2008). 
Laste esimesed eestikeelsed omadussõnad 26 